\title{
EGR1 wt Allele
}

National Cancer Institute

\section{Source}

National Cancer Institute. EGR1 wt Allele. NCI Thesaurus. Code C99600.

Human EGR1 wild-type allele is located within 5q23-q31 and is approximately 4 kb in length. This allele, which encodes early growth response protein 1 , plays a role in both mitogenesis and differentiation. 